\title{
PERMAINAN TEBAK-TEBAK BUAH MANGGIS: SEBUAH INOVASI PEMBELAJARAN MATEMATIKA BERBASIS ETNOMATEMATIKA
}

\section{(THE MANGOSTEENE GUESS GAME: A MATHEMATICS LEARNING INOVATION BASED ON ETHNOMATHEMATICS)}

\author{
Rachmaniah Mirza Hariastuti \\ Universitas PGRI Banyuwangi, mirzarachmania@gmail.com
}

\begin{abstract}
Abstrak
Kajian ini bertujuan untuk mengangkat kembali permainan tradisional "tebak-tebak buah manggis" yang sudah mulai jarang dimainkan oleh anak-anak di daerah penghasil buah manggis, khususnya di Banyuwangi. Dari permainan tradisional tersebut dikembangkan suatu permainan baru yang menghubungkan permainan tebak-tebak buah manggis dengan konsep penjumlahan dan perkalian di matematika. Hasil pengembangan menunjukkan bahwa terdapat keterbatasan dalam penerapan konsep matematika pada permainan ini. Hal ini terjadi karena adanya keterbatasan pada isi buah manggis. Namun secara umum permainan pengembangan tebak-tebak isi buah manggis ini dapat digunakan sebagai media pembelajaran matematika. Pengembangan permainan tersebut dilakukan berbasis etnomatematika.
\end{abstract}

Kata kunci: Permainan, Buah Manggis, Etnomatematika

\begin{abstract}
The study described an traditional game named "guessing mangosteen". This game rarely played by children nowadays, espescially in Banyuwangi. This game was developed into a new game that connected the geussing mangosteen with addition and multiplication concepts. The study found that there was a limition because the number of mangosteen seed limited. However, generally this new game could be applayed as mathematics learning media. The development of the new game was done based on ethnomathematics.
\end{abstract}

Keywords: Game, Mangosteene, Ethnomathematics

\section{PENDAHULUAN}

Pembelajaran matematika merupakan salah satu pembelajaran yang wajib diberikan dari jenjang sekolah dasar dan sekolah menengah di Indonesia. Banyaknya materi yang dianggap wajib untuk dikuasai oleh siswa membuat bertambahnya kesulitan siswa dalam memahami matematika. Tidak semua siswa dapat menerima materi matematika yang diberikan oleh gurunya dengan baik. Hal ini terjadi selain karena terlalu banyaknya hal yang harus dipelajari siswa, juga karena penyampaian materi yang terlalu monoton.

Beragamnya metode dan model pembelajaran seringkali dilakukan oleh guru, tetapi masih ada yang belum memberikan hasil positif. Kemampuan siswa 
yang beragam juga membuat guru harus menentukan metode dan model yang tepat sehingga konsep pembelajaran dapat tersampaikan dengan maksimal. Metode ceramah seringkali dipilih sebagai metode yang mudah untuk dapat menyampaikan konsep pada siswa. Namun sayangnya metode ini kurang dapat mengeksplorasi keaktifan dan pemahaman siswa.

Salah satu materi dalam pembelajaran matematika di sekolah dasar yang menuntut pemahaman konsep secara jelas adalah penjumlahan dan perkalian. Operasi penjumlahan dan perkalian merupakan operasi dasar pada mata pelajaran matematika. Karena merupakan operasi dasar, maka diharapkan pemahaman siswa harus benar-benar kuat sebelum dapat memahami konsep operasi yang lebih tinggi.

Untuk memudahkan siswa dalam memahami konsep dasar penjumlahan dan perkalian diperlukan cara tertentu yang sesuai dengan pemahaman siswa. Selain dengan cara konvensional, konsep dasar penjumlahan dan perkalian dapat disampaikan dengan menggunakan permainan yang secara kultural mudah dipahami oleh siswa. Karakteristik kultural dalam pembelajaran matematika dapat dikaitkan dengan etnomatematika.

Etnomatematika bukan merupakan hal yang baru dalam pembahasan matematika. Etnomatematika dapat diartikan sebagai matematika yang diterapkan oleh kelompok budaya tertentu, kelas-kelas profesional dan sebagainya (Gerdes dalam Tandililing, 2013). Selain itu etnomatematika juga dapat diartikan sebagai studi tentang hubungan antara matematika dengan latar belakang sosial budaya yang berhubungan yang menunjukkan bagaimana matematika dihasilkan, dialihkan, disebarkan dan dikhususkan dalam sistem budaya yang beragam (Zhang \& Zhang, 2010).

Dari pendefinisian di atas dapat dikatakan bahwa matematika dapat ditemukan dalam berbagai unsur budaya dan dalam kehidupan masyarakat seharihari. Akibatnya secara umum dapat dikatakan bahwa etnomatematika merupakan suatu bidang yang mempelajari cara-cara yang dilakukan manusia dari budaya yang berbeda dalam memahami, melafalkan dan menggunakan konsep dari budayanya yang berhubungan dengan matematika. Sehingga dalam etnomatematika dapat dikaji bagaimana cara orang memahami, mengekspresikan dan menggunakan konsep-konsep budaya yang digambarkan secara matematis.

Karena budaya pada tiap daerah memiliki perbedaan, maka pembelajaran yang berkaitan dengan etnomatematika juga termasuk pembelajaran yang berbasis pendidikan multikultural. Menurut Danoebroto (2012:94), "pembelajaran matematika berbasis pendidikan multikultural bertujuan untuk mengoptimalkan prestasi belajar matematika sekaligus menumbuhkan kesadaran, kesepahaman, toleransi, saling pengertian, dan semangat kebangsaan individu siswa sebagai bagian dari masyarakat yang multikultur".

Salah satu penelitian tentang etnomatematika adalah yang dilakukan oleh Tandililing (2013:MP-201) tentang pengembangan etnomatematika berbasis budaya lokal di Kalimantan Barat. Dari penelitian tersebut diperoleh hasil bahwa terdapat bentuk aktivitas masyarakat Dayak Kanayatu yang bernuansa matematika yang bersifat operasi hitung (seperti: menjumlah, mengurang, membilang, mengukur, menentukan lokasi, merancang bangun dan bermain), materi bilangan dan lambangnya, membandingkan dan mengurutkan bilangan, serta geometri (seperti: titik, garis, sudut, pojok, bangun datar dan bangun ruang) yang dapat 
dikembangkan pada beberapa materi pelajaran matematika khususnya SD. Penelitian tersebut menunjukkan adanya potensi lokal dari suatu daerah yang dapat dikaitkan dengan pembelajaran matematika.

Penelitian lain yang dilakukan oleh Hartoyo (2012:14) terhadap masyarakat Dayak perbatasan Indonesia-Malaysia Kabupaten Sanggau Kalimantan Barat, menunjukkan bahwa etnomatematika digunakan oleh masyarakat ketika mereka melakukan aktivitas sehari-hari, atau melaksanakan berbagai upacara adat. Konsep matematika (geometri) yang lebih rumit diterapkan oleh masyarakat pada motif-motif anyaman topi. Hal ini menunjukkan adanya keterkaitan antara kehidupan sehari-hari sekumpulan masyarakat dengan konsepkonsep dalam matematika.

Setiap daerah di Indonesia pasti memiliki potensi lokal yang beragam. Salah satunya adalah Banyuwangi. Banyuwangi merupakan kota di ujung timur pulau Jawa yang memiliki wilayah yang cukup luas. Berbagai potensi dimiliki Banyuwangi, baik budaya maupun keragaman alam dan hayati. Pengembangan potensi-potensi tersebut terus diupayakan oleh pemerintah kabupaten Banyuwangi untuk memperkenalkan Banyuwangi.

Salah satu potensi yang terdapat di Banyuwangi adalah buah manggis. Produksi buah manggis yang melimpah antara bulan Januari hingga Juni selama ini dimanfaatkan masyarakat Banyuwangi sebagai konsumsi sehari-hari (baik konsumsi di Banyuwangi sendiri, di luar Banyuwangi, maupun ekspor). Keberadaan buah manggis yang unik dengan banyak kelopak kulit buah yang sama dengan banyak isi buahnya membuat buah manggis sering digunakan oleh anak-anak untuk permainan tebak-tebakan.

Permainan yang dimaksud adalah dengan mencocokan antara banyak kelopak kulit buah manggis dengan banyak isinya. Permainan sederhana ini biasanya dilakukan anak-anak dengan pola yang sederhana. Dari pengamatan tersebut, akan dirancang suatu permainan yang pada dasarnya berupa tebaktebakan tentang kecocokan banyak kelopak kulit buah dengan banyak isi buah manggis. Permainan ini akan dihubungkan dengan konsep penjumlahan dan perkalian yang diterima siswa di Sekolah Dasar.

\section{BAHASAN UTAMA}

Pembelajaran matematika mulai tingkat dasar hingga tingkat tinggi secara umum merupakan pembelajaran yang tidak mudah untuk dipahami. Keabstrakan obyek dalam matematika membuat dibutuhkannya hal-hal yang dekat dengan kehidupan sehari-hari untuk membantu pemahaman siswa. Pemahaman terhadap materi matematika seharusnya dilakukan sejak siswa berada pada tingkat dasar.

Matematika merupakan salah satu mata pelajaran yang berperan penting dalam kehidupan sehari-hari. Selain digunakan dalam kehidupan sehari-hari, matematika sendiri juga dapat dikembangkan melalui hal-hal yang ada dalam kehidupan sehari-hari. Implikasi karakteristik kultural dalam pembelajaran matematika dikenal sebagai etnomatematika.

Pembahasan tentang etnomatematika dipelopori pada tahun 1985 oleh Ubiratan D'Ambrosio. Menurut Barton (dalam Wahyuni, Tias, \& Sani, 2013:115116), "Ethnomathematics is a field of study which examines the way people from other cultures understand, articulated and use concepts and practices which are from their culture and which the researcher describes as mathematics". Artinya 
etnomatematika merupakan suatu bidang yang mempelajari cara-cara yang dilakukan manusia dari budaya yang berbeda dalam memahami, melafalkan dan menggunakan konsep dari budayanya yang berhubungan dengan matematika. Sehingga dalam etnomatematika dapat dikaji bagaimana cara orang memahami, mengekspresikan dan menggunakan konsep-konsep budaya yang digambarkan secara matematis.

Sedangkan Rachmawati (2012:1) mendefinisikan etnomatematika sebagai cara-cara khusus yang dipakai oleh suatu kelompok budaya atau masyarakat tertentu dalam aktivitas matematika. Aktivitas matematika yang dimaksud adalah aktivitas yang didalamnya terjadi proses pengabstraksian dari pengalaman nyata dalam kehidupan sehari-hari kedalam matematika atau sebaliknya. Aktivitas tersebut dapat dijumpai pada kehidupan sehari-hari, seperti penggunaan konsepkonsep geometri dalam arsitektur rumah-rumah adat, konsep-konsep aritmetika sosial dalam perdagangan, konsep-konsep aritmetika sederhana dalam permainan anak-anak, dan lain-lain. Hal ini menunjukkan bahwa konsep-konsep matematika telah dipahami oleh masyarakat di masa lampau dan diterapkan dalam konsep budaya.

Kajian ini dimulai dari potensi yang dapat ditemui di Banyuwangi. Kabupaten Banyuwangi yang memiliki julukan "The Sunrise of Java", yang artinya matahari terbitnya pulau Jawa, memiliki banyak potensi alam dan keragaman hayati yang dapat dikembangkan hingga hasilnya tidak hanya dinikmati masyarakat Banyuwangi sendiri, tetapi juga diekspor. Salah satu komoditi yang dihasilkan oleh kabupaten Banyuwangi adalah buah manggis.

Manggis (Garcinia mangostana L.) merupakan salah satu buah tropik yang digemari oleh masyarakat dari anak-anak hingga dewasa. Manggis memiliki julukan Queen of tropical atau ratunya buah tropik (Cox dalam Qosim, 2013). Buah manggis memiliki bagian dari kulit yang konsisten dengan isi buahnya. Artinya banyak kelopak pada kulit buah sama dengan banyak isi buahnya. Dengan kondisi tersebut, buah manggis dapat digunakan untuk suatu permainan menebak banyak isi dari beberapa buah manggis.

Banyuwangi merupakan salah satu kabupaten di Indonesia yang menjadi sentra utama manggis yang tidak hanya dikonsumsi di Indonesia tetapi juga untuk diekspor (Sasmita, Nasution, \& Indarwatmi, 2013). Kondisi tersebut membuat manggis menjadi bagian dari budaya daerah Banyuwangi. Dalam Hortus online archipelago, dikatakan bahwa Banyuwangi dikenal sebagai sentra produksi manggis terbesar di Jawa Timur. Buah manggis asal Banyuwangi merupakan pasokan utama bagi pasar modern di Jakarta, Bandung, Surabaya, Denpasar, dan beberapa kawasan lain di Indonesia. Selain itu manggis Banyuwangi juga mampu menembus pasar ekspor. Di antaranya China, Taiwan, Singapura dan Timur Tengah.

Sentra kawasan manggis di Banyuwangi tersebar di 7 Kecamatan, yaitu Kecamatan Kalipuro, Songgon, Sempu, Glenmore, Licin, Glagah dan Giri. Ratarata produksi manggis di Banyuwangi bisa mencapai 17.289 ton per tahun dengan masa panen Januari-Juni. Hal ini menyebabkan Banyuwangi menjadi sentra manggis di Jawa Timur dengan total produksi sebanyak 20.199 ton pada 2013. Luasan tanaman manggis di Banyuwangi mencapai 1.590,5 hektar, yang tersebar di 6 kecamatan yakni Kalipuro, Glagah, Licin, Songgon, Sempu, dan Glenmore. 
Penyumbang hasil manggis terbesar di Banyuwangi adalah kecamatan Kalipuro. Dari dialog yang dilakukan dengan warga sekitar diperoleh keterangan bahwa manggis yang dihasilkan akan disetorkan pada pengumpul buah untuk kemudian diseleksi. Manggis dengan ukuran tertentu (sedang hingga besar) dan kondisi baik akan dipisahkan untuk komoditi nusantara dan ekspor. Sedangkan manggis yang ukurannya kecil hingga sedang akan dijual di dalam kota Banyuwangi sendiri. Hal ini menunjukkan bahwa masih banyak buah manggis yang dapat dikonsumsi oleh masyarakat Banyuwangi sendiri, khususnya di daerah penghasil manggis tersebut.

Buah manggis yang masih tertinggal selain dijual ke penjual buah di kota Banyuwangi juga dikonsumsi sendiri oleh masyarakat setempat. Secara khusus anak-anak yang mengkonsumsi buah tersebut seringkali menggunakannya sebagai permainan bersama teman-temannya. Permainan tersebut sederhana namun unik. Permainan menebak banyak isi buah manggis, dilakukan dengan cara membilang banyak kelopak pada kulit buah manggis. Hal ini dapat dilakukan karena keunikan buah manggis terletak pada adanya kesamaan banyak kelopak pada kulit buah dengan banyak isi buahnya.

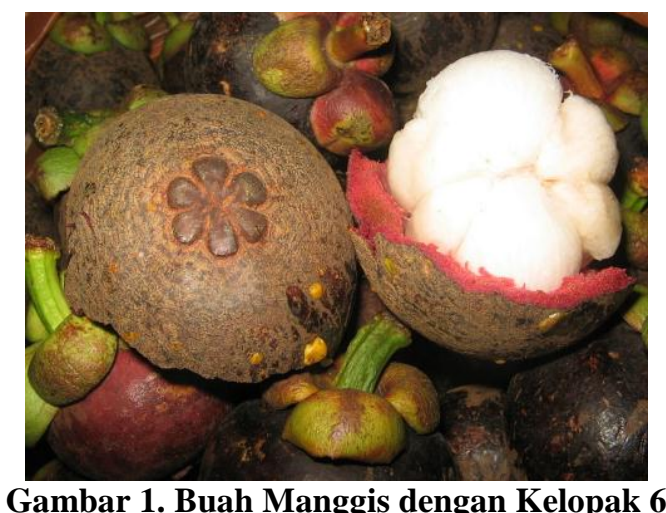

Keunikan tersebut dapat dikembangkan sebagai media pembelajaran khususnya matematika. Perancangan konsep penggunaan manggis sebagai media pembelajaran berjalan secara induktif dengan menggunakan contoh-contoh dahulu kemudian dibuat kesimpulan. Permainan ini dirancang untuk dapat dilakukan di dalam atau di luar kelas. Bahkan jika memungkinkan dapat pula dilakukan langsung di kebun manggis.

Permainan ini dapat dinamakan "tebak-tebak buah manggis", yang diawali dengan membentuk siswa menjadi berkelompok terdiri dari 4-6 orang. Dari tiaptiap kelompok akan terpecah masing-masing menjadi dua kelompok.

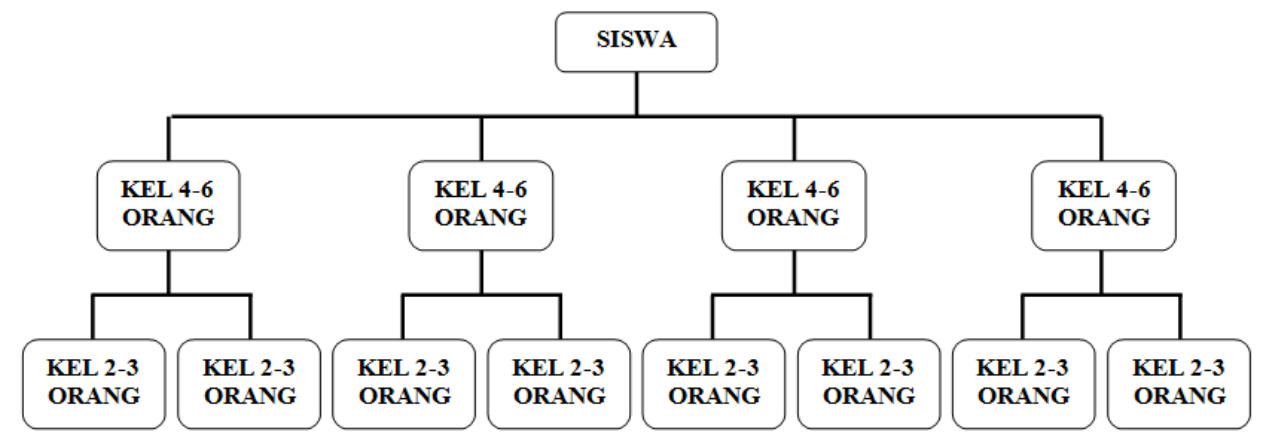

Gambar 2. Diagram Pembagian Kelompok Permainan 
Tiap-tiap kelompok akan disediakan sekeranjang buah manggis untuk digunakan sebagai media permainan menebak isi buah manggis.

Permainan ini dapat digunakan untuk memahamkan konsep penjumlahan, yang sasarannya adalah siswa kelas 1 Sekolah Dasar. Konsep permainan didasarkan pada definisi penjumlahan. Secara umum konsep penjumlahan dapat didefinisikan melalui hubungan antar himpunan. Jika diketahui himpunan $A$ dengan $a$ anggota dan himpunan $B$ dengan $b$ anggota, sedangkan $A$ dan $B$ merupakan himpunan yang saling lepas $(A \cap B=\phi)$, maka yang dimaksud dengan $a+b$ adalah banyak anggota $A \cup B$. Sehingga $a+b=n(A \cup B)$. Penggambaran konsep ini dasajikan pada gambar berikut.

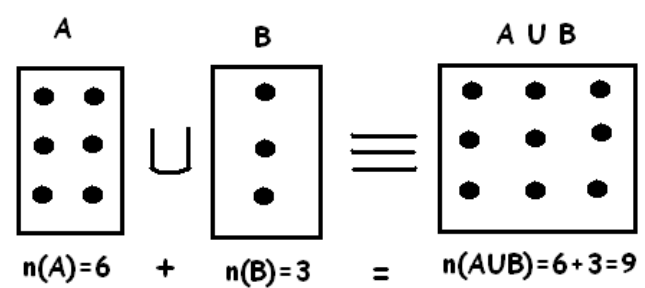

\section{Gambar 3. Contoh Penggambaran Konsep Penjumlahan}

Berdasarkan definisi di atas, maka satu buah manggis dapat dianggap sebagai himpunan yang di dalamnya memuat anggota himpunan berupa isi dari buah manggis. Adapun kelopak kulit buah manggis digunakan sebagai bagian dari tebakan awal. Permainan dapat diawali dari guru mencontohkan proses permainan. Jika diambil satu buah manggis dengan kelopak kulit sebanyak 5, kemudian diambil satu buah manggis lagi dengan kelopak kulit sebanyak 5, maka siswa dapat diminta untuk menebak berapa banyak isi buah manggis yang bisa dimakannya.

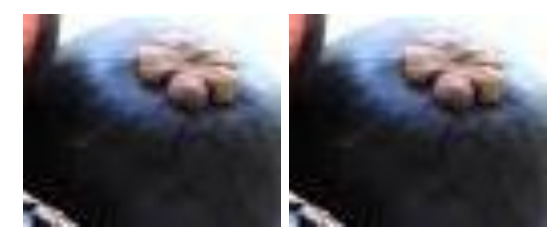

Gambar 4. Buah Manggis dengan Kelopak 5

Siswa dapat menjumlahkan banyak kelopak kulit buah manggis, selanjutnya membuktikan hasil perhitungan dengan cara membuka buah manggis dan membilang banyak isinya. Dengan membuktikan bahwa banyak isi kedua buah manggis adalah 10, maka siswa dikatakan berhasil menebak hasil dari $5+5$.

Proses berikutnya, tiap kelompok diminta berhadapan. Kelompok pertama memberikan tebakan pada kelompok kedua, dan seterusnya. Misalnya kelompok pertama mengambil satu buah manggis dengan kelopak kulit sebanyak 5, dan satu buah manggis lain dengan kelopak kulit sebanyak 6. Kelompok kedua diminta menebak berapa banyak isi dari dua buah manggis tersebut.
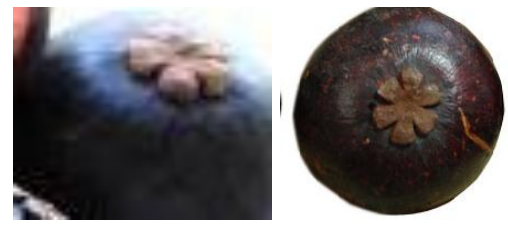

Gambar 5. Buah Manggis dengan Kelopak 5 dan 6 
Siswa dapat menjumlahkan banyak kelopak kulit buah manggis. Selanjutnya siswa akan membuktikan hasil perhitungannya dengan cara membuka buah manggis dan membilang banyak isinya. Dengan membuktikan bahwa banyak isi kedua buah manggis adalah 11, maka siswa dikatakan berhasil menebak hasil dari $5+6$.

Proses ini dapat dilanjutkan terus hingga siswa memahami konsep penjumlahan tersebut atau hingga buah yang disediakan habis. Dengan memberi kesempatan pada siswa membuat pertanyaan sendiri, guru sekaligus juga dapat membuat siswa berkreasi dengan konsep penjumlahan tersebut. Selain konsep penjumlahan dasar itu sendiri, guru juga dapat memahamkan konsep sifat komutatif penjumlahan pada siswa. Misalnya diambil satu buah manggis dengan kelopak kulit sebanyak 5, dan satu buah manggis lain dengan kelopak kulit sebanyak 6. Kemudian siswa diminta menebak berapa banyak isi dari dua buah manggis tersebut. Setelah siswa dapat menjumlahkan banyak kelopak kulit buah manggis, selanjutnya siswa diminta membuktikan hasil perhitungannya dengan cara membuka buah manggis dan membilang banyak isinya. Dengan membuktikan bahwa banyak isi kedua buah manggis adalah 11, maka siswa dikatakan berhasil menebak hasil dari $5+6$.

Selanjutnya diambil satu buah manggis dengan kelopak kulit sebanyak 6, dan satu buah manggis lain dengan kelopak kulit sebanyak 5 .

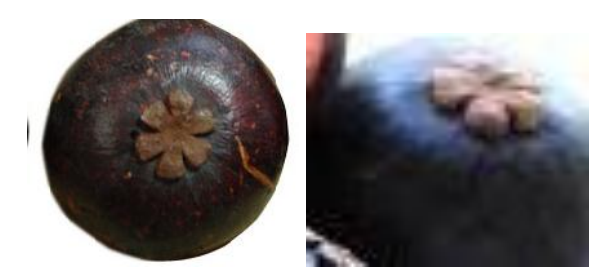

Gambar 6. Buah Manggis dengan Kelopak 6 dan 5

Kemudian siswa diminta menebak berapa banyak isi dari dua buah manggis tersebut. Setelah siswa dapat menjumlahkan banyak kelopak kulit buah manggis, selanjutnya siswa diminta membuktikan hasil perhitungannya dengan cara membuka buah manggis dan membilang banyak isinya. Dengan membuktikan bahwa banyak isi kedua buah manggis adalah 11, maka siswa dikatakan berhasil menebak hasil dari $6+5$.

Dari kedua proses di atas, siswa diminta mencermati bahwa hasil dari $5+6$ sama dengan $6+5$. Kemudian siswa diminta untuk mencoba contoh-contoh yang lain. Dengan diperolehnya hasil yang sama, siswa secara tidak langsung akan dapat menyimpulkan suatu konsep $a+b=b+a$ atau yang disebut sifat komutatif pada penjumlahan.

Jika permainan ini digunakan untuk memahamkan konsep perkalian, maka sasarannya adalah siswa kelas 2 Sekolah Dasar. Konsep permainan didasarkan pada definisi perkalian. Konsep perkalian secara umum didefinisikan sebagai penjumlahan berganda/berulang dari $a$ suku, yang masing-masing sukunya adalah $b$, atau $a \times b=\underbrace{b+b+b+\ldots+b}_{\text {asuku }}$. Jika $a \times b$ disebut sebagai $c$, sehingga $a \times b=c$, maka $a$ disebut sebagai "pengali", $b$ disebut sebagai "terkali" (bilangan yang dikalikan), dan $c$ disebut sebagai "hasil kali", contohnya sebagai berikut. 


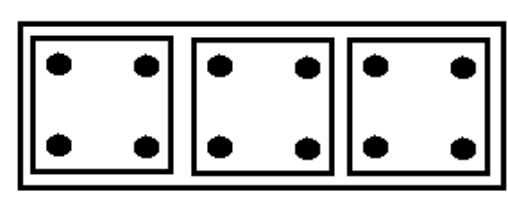

Penggambaran $3 \times 4$

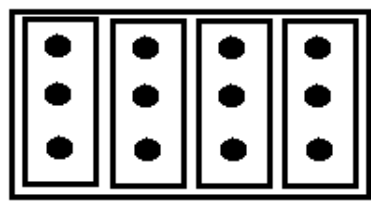

Penggambaran $4 \times 3$

Gambar 7. Contoh Penggambaran Konsep Perkalian

Berdasarkan definisi di atas, maka dapat ditentukan sekumpulan buah manggis dengan banyak kelopak kulit yang sama. Permainan dapat diawali dari guru mencontohkan proses permainan. Diambil 5 buah manggis yang masingmasing memiliki kelopak kulit sebanyak 6. Kemudian siswa dapat diminta untuk menebak berapa banyak isi dalam keseluruhan buah manggis tersebut.
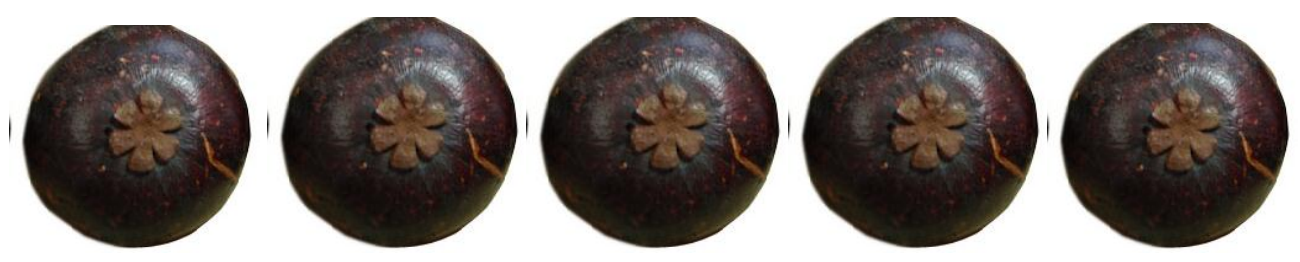

Gambar 8. Buah Manggis untuk Menunjukkan Konsep $5 \times 6$

Konsep perkalian yang dapat ditunjukkan ke siswa adalah $5 \times 6$ yang artinya $6+6+6+6+6$. Siswa dapat menghitung terlebih dahulu hasil dari $5 \times 6$, kemudian mencocokan dengan isi buahnya.

Proses berikutnya, tiap kelompok diminta berhadapan. Kelompok pertama memberikan tebakan pada kelompok kedua, dan seterusnya. Misalnya kelompok pertama mengambil 3 buah manggis dengan kelopak kulit sebanyak 7.
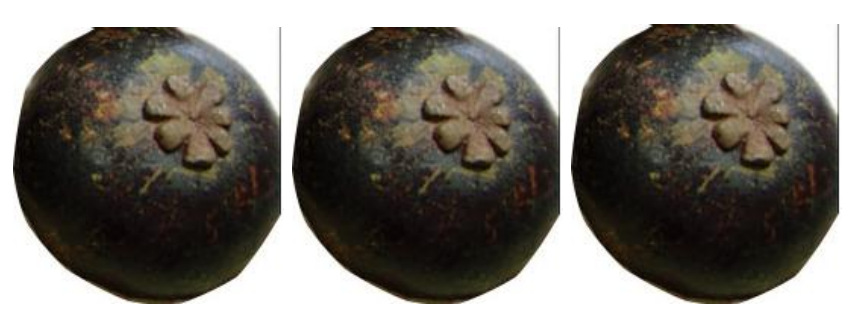

Gambar 9. Buah Manggis untuk Menunjukkan $3 \times 7$

Kelompok kedua diminta menebak berapa banyak isi dari keseluruhan buah manggis tersebut. Konsep perkalian yang dapat ditunjukkan ke siswa adalah $3 \times 7$ yang artinya $7+7+7$. Siswa dapat menghitung terlebih dahulu hasil dari $3 \times 7$, kemudian mencocokan dengan isi buahnya.

Proses ini dapat dilanjutkan terus hingga siswa memahami konsep perkalian atau hingga buah yang disediakan habis. Dengan memberi kesempatan pada siswa membuat pertanyaan sendiri, guru sekaligus juga dapat membuat siswa berkreasi dengan konsep perkalian tersebut. Selain konsep perkalian dasar itu sendiri, guru juga dapat memahamkan konsep sifat komutatif perkalian pada siswa. Konsep sifat komutatif yang harus dipahamkan pada siswa adalah hasil yang sama dari sifat komutatif tersebut tetapi proses yang dilalui berbeda. 
Misalnya diambil 5 buah manggis yang masing-masing memiliki kelopak kulit sebanyak 6. Kemudian siswa diminta menebak berapa banyak isi dari keseluruhan buah manggis tersebut. Setelah siswa dapat menentukan banyak keseluruhan kelopak kulit buah manggis, siswa diminta membuktikan hasil perhitungannya dengan cara membuka buah manggis dan membilang banyak isinya. Konsep yang ditunjukkan dalam proses tersebut adalah $5 \times 6=6+6+6+6+6$. Jika siswa dapat menunjukkan bahwa hasilnya adalah 30 , berarti siswa mendapatkan hasil yang benar.

Selanjutnya diambil 6 buah manggis dengan kelopak kulit sebanyak 5 . Siswa diminta menebak berapa banyak isi dari keseluruhan buah manggis tersebut.
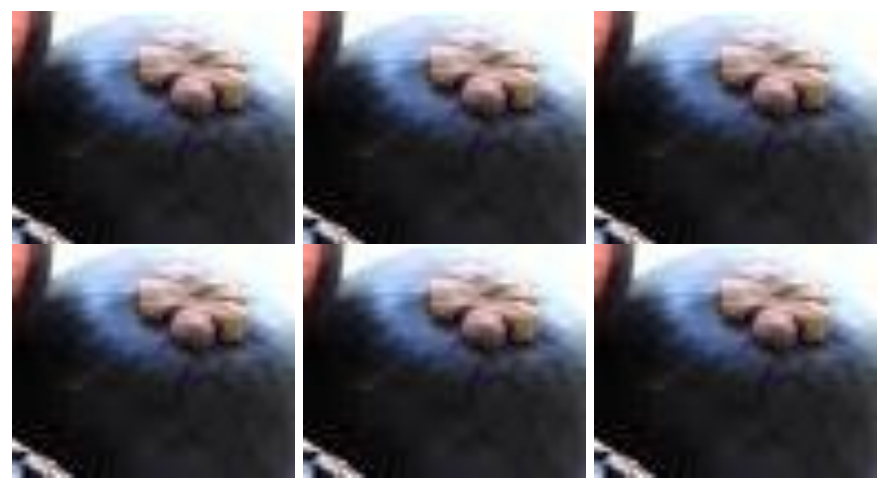

Gambar 10. Buah Manggis untuk Menunjukkan Konsep $6 \times 5$

Setelah siswa dapat menentukan banyak keseluruhan kelopak kulit buah manggis, selanjutnya siswa diminta membuktikan hasil perhitungannya dengan cara membuka buah manggis dan membilang banyak isinya. Konsep yang ditunjukkan dalam proses tersebut adalah $6 \times 5=5+5+5+5+5+5$. Jika siswa dapat menunjukkan bahwa hasilnya adalah 30 , berarti siswa mendapatkan hasil yang benar. Hasil dari kedua contoh di atas, dapat digunakan guru untuk mengenalkan sifat komutatif pada perkalian. Hasil dari perkalian tersebut adalah sama, tetapi proses untuk memperolehnya berbeda.

Permainan di atas dapat divariasi sesuai dengan keberadaan buah manggis. Kendala yang dihadapi dalam permainan tebak- tebak buah manggis ini adalah tidak selalu diperoleh buah manggis dengan banyak kelopak yang diinginkan. Secara umum buah manggis memiliki isi antara 5-7.

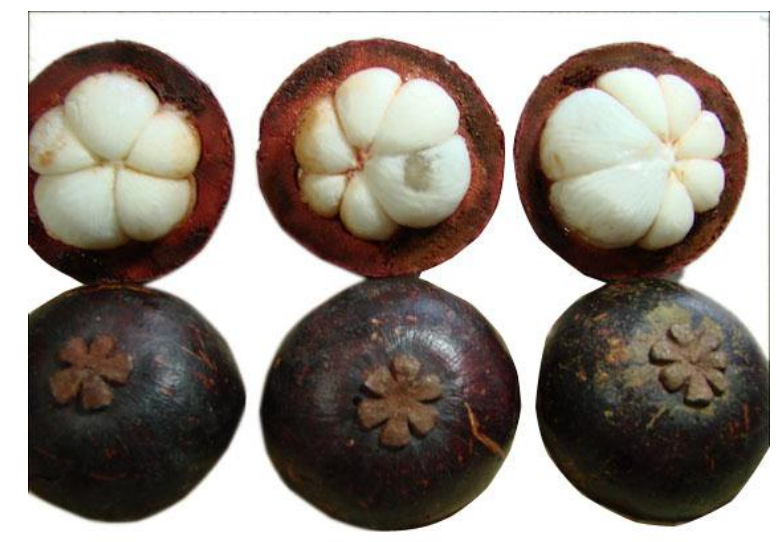

Gambar 11. Buah Manggis dengan Kelopak 5, 6, dan 7 
Sehingga tidak dapat tersampaikan konsep penjumlahan dengan dasar bilangan 14 dan lebih dari 8. Namun karena konsep dari penggunaan buah manggis ini hanya sebagai permainan (penguatan konsep), maka dapat digunakan buah manggis yang ada.

Pembelajaran matematika dengan menggunakan buah manggis ini merupakan salah satu contoh pembelajaran yang berbasis etnomatematika. Penggunaan sumber daya alam sebagai media pembelajaran diharapkan dapat membuat siswa lebih memahami materi yang disampaikan karena proses penyampaian yang tidak monoton, membuat siswa memahami dan lebih mencintai keanekaragaman hayati yang ada dilingkungannya, serta melestarikan permainan-permainan sederhana yang ada di masyarakat.

\section{SIMPULAN}

Dari pembahasan di atas dapat disimpulkan bahwa permainan sederhana anak-anak yang umumnya hanya digunakan untuk mengisi waktu luang, dapat dijadikan inspirasi untuk memperkaya pembelajaran matematika. Salah satunya adalah permainan tebak-tebak buah manggis yang dapat dikembangkan menjadi media untuk menyampaikan konsep penjumlahan dan perkalian di Sekolah Dasar. Pengembangan permainan ini selain untuk melestarikan budaya melalui permainan tradisional yang sudah jarang sekali dimainkan, juga untuk memperkaya bahan pembelajaran etnomatematika.

Sebagai bahan kajian untuk penelitian sejenis, dapat dikembangkan lebih jauh permainan tersebut untuk konsep-konsep lain dalam matematika. Pengkajian terhadap budaya khususnya permainan anak-anak tradisional yang sudah jarang sekali dimainkan yang dihubungkan dengan pembelajaran matematika, diharapkan dapat membuat guru lebih mudah memahamkan siswa terhadap suatu materi.

\section{DAFTAR RUJUKAN}

Danoebroto, S. W. (2012). Model pembelajaran matematika berbasis pendidikan multikultural. Jurnal Pembangunan Pendidikan: Fondasi dan Aplikasi, 1(1), 94-107.

D'Ambrosio, U. (2001). Ethnomathematics and mathematics education. Dalam Proceedings of the $10^{\text {th }}$ International Congress of Mathematics Education Copenhagen diselenggarakan pada 4-11 Juli 2004. Pisa: Dipartimento di Matematica, Universita` di Pisa.

Hartoyo, A. (2012). Eksplorasi etnomatematika pada budaya masyarakat dayak perbatasan Indonesia Malaysia Kabupaten Sanggau Kalbar. PenelitianPendidikan, 12(1).

Qosim, W. A. (2013). Pengembangan buah manggis sebagai komoditas ekspor Indonesia. Jurnal Kultivasi, 12(1), 40-45.

Rachmawati, I. (2012). Eksplorasi etnomatematika masyarakat sidoarjo [Versi Elektronik]. MATHEdunesa, 1(1).

Hortus. (2015). Sejak 2009, manggis asal Banyuwangi masuk China [Majalah online]. Diakses dari http://www.majalahhortus.com/jendela/item/71-sejak2009-manggis-asal-banyuwangi-masuk-china.html.

Sasmita, H. I., Nasution, I. A., \& Indarwatmi, M. (2013). Perbedaan penampilan buah manggis (garcia mangostana 1.) pasca iradiasi sinar gamma dalam 
berbagai dosis. Dalam Prosiding Seminar Nasional Sains dan Teknologi Nuklir PTNBR-BATAN Bandung diselenggarakan pada 4 Juli 2013. Bandung: FMIPA UNPAD.

Tandililing, E. (2013). Pengembangan pembelajaran matematika sekolah dengan pendekatan etnomatematika berbasis budaya lokal sebagai upaya untuk meningkatkan kualitas pembelajaran matematika di sekolah. Dalam Prosiding Seminar Nasional Matematika dan Pendidikan Matematika diselenggarakan pada 9 November 2013. Yogyakarta: Jurusan Pendidikan Matematika FMIPA UNY.

Wahyuni, A., Tias, A. A. W., \& Sani, B. (2013). Peran etnomatematika dalam membangun karakter bangsa. Dalam Prosiding Seminar Nasional Matematika dan Pendidikan Matematika diselenggarakan pada 9 November 2013. Yogyakarta: Jurusan Pendidikan Matematika FMIPA UNY.

Zhang, W., \& Zhang, Q. (2010). Ethnomathematics and its integration within the mathematics curriculum. Journal of Mathematics Education, 3(1), 151-157. 